\title{
Pre- and post-settlement factors as determinants of juvenile blue crab Callinectes sapidus abundance: results from the north-central Gulf of Mexico
}

\author{
K. L. Heck Jr ${ }^{1,2, *}$, L. D. Coen $^{3}$, S. G. Morgan ${ }^{4}$ \\ ${ }^{1}$ Dauphin Island Sea Laboratory and ${ }^{2}$ Department of Marine Sciences, University of South Alabama, 101 Bienville \\ Boulevard, Dauphin Island, Alabama 36528, USA \\ ${ }^{3}$ Marine Resources Research Institute, South Carolina Department of Natural Resources, 217 Fort Johnson Road, Charleston, \\ South Carolina 29412, USA \\ ${ }^{4}$ Bodega Marine Laboratory, University of California, PO Box 247, Bodega Bay, California 94923, USA
}

\begin{abstract}
We estimated juvenile abundance and predation potential for young-of-the-year (YOY) blue crabs Callinectes sapidus in upper- and lower-salinity marsh and submerged aquatic vegetation (SAV) 'nursery habitats' of Mobile Bay, Alabama, USA, and surrounding waters, and combined this information with previously published post-larval abundance data from these habitats to evaluate the relative roles of pre- and post-settlement events in determining the abundance of YOY crabs. We found little evidence for a significant relationship between megalopal supply and juvenile abundance, except shortly after a few very large, episodic pulses of postlarvae. However, even after large settlement events, in less than $14 \mathrm{~d}$ densities of YOY crabs had declined in a density-dependent manner to prior 'background' levels. These declines in density were probably due to high predation rates that produced as much as $95 \%$ mortality on a daily basis. As many previous studies had found, greater predation risk was recorded for crabs on unvegetated substrate than for those in SAV or marsh grass. Overall, losses to predators were high at our study sites compared to those reported in similar studies along the Atlantic coast of the United States. In both years of the study (1990 and 1991), the largest numbers of juvenile crabs were found in poly- and mesohaline SAV and salt marsh habitats. In Year 1, no significant correlations were observed between either marsh stem density or SAV vegetation biomass and YOY crab abundance, although at one location in the second year there was a significant positive correlation between the number of juveniles and mid-bay stem density. No significant differences in crab size (carapace width, CW) were found among locations in either year. In comparison with other, better-studied mid-Atlantic coast estuaries in the US (e.g., the Chesapeake and Delaware bays), very large numbers of megalopae (frequently 1 to 2 orders of magnitude greater) invade the Mobile Bay system, as well as other Gulf Coast estuaries. However, YOY abundance in marsh and SAV 'nursery habitats' was of the same order of magnitude as that reported for mid-Atlantic estuaries. We conclude that although postlarval supply was very large, post-settlement loss to predators was the dominant factor influencing blue crab population dynamics in our north central Gulf of Mexico study area.
\end{abstract}

KEY WORDS: Recruitment $\cdot$ Post-settlement mortality $\cdot$ Blue crab $\cdot$ Callinectes sapidus

\section{INTRODUCTION}

Understanding the factors responsible for dramatic fluctuations characteristic of marine species with com-

*E-mail: kheck@disl.org plex life cycles has long been a primary goal for fisheries biologists and marine ecologists. Intuitively, one might expect that the abundance of adult populations should be significantly correlated with the magnitude of prior spawning events. However, only rarely have intensively studied fishery species shown clear rela- 
tionships between egg and larval production and the subsequent abundance of adults (Cushing 1982, Sissenwine 1984, Rothschild 1986). In contrast, marine ecologists have frequently reported strong correspondences between larval supply and the abundance of adult invertebrates (e.g., Gaines et al. 1985, Gaines \& Bertness 1992). To date, few generalizations have emerged regarding the circumstances in which one might expect strong stock-recruitment relationships, although species with short larval development times and those inhabiting bays with low flushing rates seem most likely to exhibit close correspondence between larval supply and the abundance of newly-settled juveniles.

The blue crab Callinectes sapidus ranges from Canada to Brazil (Williams 1984), and is one of the most ecologically (Hines et al. 1990, Olmi \& Orth 1995) and commercially (NMFS 1988) important species in the western Atlantic Ocean and Gulf of Mexico. The commercial importance of this species has generated considerable research on the biology of adults. However, like many commercially important marine species, blue crabs have a complex life cycle that includes many larval stages. Despite exhaustive research on adult blue crabs along the Atlantic coast, our knowledge of the ecology of larvae and juveniles is less than complete and comes primarily from relatively recent studies conducted mainly along the mid-Atlantic US coast from Delaware to Georgia (Epifanio 1995, Mense et al. 1995, Metcalf et al. 1995, Olmi 1995, van Montfrans et al. 1995, Wrona et al. 1995, Blanton et al. 1996, Pile et al. 1996, Moksnes et al. 1997).

In the past few years it has become clear that recruitment patterns can vary considerably throughout the range of the blue crab, with large differences in postlarval supply existing between Gulf and Atlantic coast estuaries in the US (Perry et al. 1995, Rabalais et al. 1995, van Montfrans et al. 1995, Morgan et al. 1996). Factors that vary over the vast range of blue crabs and may be expected to affect recruitment to adult populations include size of estuaries, tidal regime, magnitude of tidal amplitude, speed and direction of prevailing winds, coastal and estuarine current regimes, abundance and diversity of predators, and types of habitat available for juvenile crabs (Perry 1975, Heck \& Thoman 1984, Orth \& van Montfrans 1987, Wilson et al. 1987, Epifanio 1995, Olmi 1995, Blanton et al. 1996). At present, our ability to predict adult population sizes and, therefore, annual harvests of blue crabs is extremely limited due to an incomplete understanding of the impact that such physical and biological factors have on recruitment and survival of young blue crabs.

Blue crabs are abundant and active benthic predators that depend heavily upon submerged aquatic veg- etation (SAV) and salt marshes as 'nursery' areas. As many as $90 \%$ of the juveniles in a given area may occur in seagrasses or marshes (Perry 1975, Heck \& Orth 1980, Penry 1982, Weinstein \& Brooks 1983, Heck \& Thoman 1984, Orth \& van Montfrans 1987), and as many as $95 \%$ of the blue crabs collected in these habitats are less than $25 \mathrm{~mm}$ CW (Zimmerman \& Minello 1984, Orth \& van Montfrans 1987, Williams et al. 1990). Positive correlations between the areal extent of SAV and the production of commercially important species have been well documented for a variety of estuarine taxa (Thayer \& Stuart 1974, Turner 1977, Nixon 1980, Boesch \& Turner 1984). However, not all vegetated habitats are equally important to the survival of populations of commercial species, including blue crabs. For example, young juvenile blue crabs are much more abundant in seagrass beds (Zostera marina, Ruppia maritima and Halodule wrightii) than in adjacent marshes (Spartina alterniflora) (Orth \& van Montfrans 1987, Thomas et al. 1990).

Because the abundance of juvenile blue crabs depends upon the supply of postlarvae (megalopae) entering nearshore nursery areas, as well as the subsequent survival of postlarval and juveniles, low densities of juvenile blue crabs in some habitats may be due either to high mortality rates or to few settlers. In the Chesapeake Bay, little correspondence exists between post-larval and juvenile blue crab abundance, suggesting that post-settlement processes dominate there (Pile et al. 1996, Moksnes et al. 1997, Orth \& van Montfrans 1987). In the Gulf of Mexico, very limited information was available on contemporaneous patterns of habitat use, settlement rates and post-settlement mortality of blue crabs prior to our work. Therefore, in a companion study, we first reported on estimates of the abundance of megalopae, and determined their settlement patterns and substrate preferences (Morgan et al. 1996). Here, we focus on the newly settled juvenile blue crabs in selected 'nursery' habitats throughout Mobile Bay and adjacent coastal waters. We anticipated that mortality rates would differ greatly between study sites and habitats, primarily due to shifts in the abundance and composition of predators and vegetation, and we used tethering experiments to address this issue.

Our overall research plan, including the work reported by Morgan et al. (1996), was designed to: (1) assess the relative roles of pre- (postlarval supply) and post- (predation losses) settlement events in determining the abundance of YOY blue crabs in estuarine 'nursery' habitats; and (2) evaluate the relative value of upper- and lower-Bay SAV and marsh habitats for YOY blue crabs. Ultimately, we expect that our work will provide information relevant to the management of Gulf of Mexico blue crab populations. 


\section{METHODS}

Study species. Blue crabs, Callinectes sapidus, may attain marketable size in coastal Alabama in less than 1 yr (Adkins 1972, Tatum 1982), which partially explains their potential for commercial exploitation. Historically, most blue crabs have been harvested from the Chesapeake Bay and South Atlantic Bight. However, blue crab landings from the Gulf of Mexico have recently surpassed those from the South Atlantic and, during the late 1980s nearly equaled those from Chesapeake Bay. For example, blue crab harvests in the Gulf of Mexico during 1987 had an ex-vessel value of US\$ 37 million, second in regional economic value only to shrimp (NMFS 1988).

From February to September, ovigerous blue crabs migrate to the mouths of estuaries in the Gulf of Mexico to release larvae (Daugherty 1952, More 1969, Adkins 1972, Perry 1975, Milliken \& Williams 1984). Larvae may be transported as far as $100 \mathrm{~km}$ offshore (Tagatz 1968, Smyth 1980, Truesdale \& Andryszak 1983), where they feed and develop for approximately 31 to $49 \mathrm{~d}$ before metamorphosing to a postlarval or megalopal, stage (Costlow \& Bookhout 1959). After spending 6 to $20 \mathrm{~d}$ in the plankton (Costlow \& Bookhout 1959), megalopae reenter estuaries, settling in shallow 'nursery habitats', and molt to the first crab stage. Megalopal reinvasion of estuaries in the northern Gulf of Mexico can occur from March to November, but appears to be greatest during late summer and early fall, with a smaller peak occurring during spring (Adkins 1972, Stuck \& Perry 1981, Rabalais et al. 1995, Morgan et al. 1996). We therefore sampled megalopae (see Morgan et al. 1996) and juveniles from summer through fall, when they were present in greatest numbers.

Study sites. Four sites spanning a broad range of physical and biological environments around Mobile Bay and Mississippi Sound, Alabama, USA, were chosen for the study (Fig. 1). These were: (1) a Dauphin Island salt marsh near the mouth of the Bay, seaward of the airport at Dauphin Island; (2) Point aux Pins, a protected SAV-marsh area on Grand Bay; (3) Fowl River, a marshdominated area on a sub-estuary on the bay's western shore; and (4) a delta site containing both freshwater marsh and SAV habitats in upper Mobile Bay's Meaher State Park.

The Dauphin Island site was used for both megalopae and juvenile collections, but only in the first year of study (1990). Average salinity recorded dur- ing biweekly sampling was 24.0 psu. Quantitative sampling for YOY crabs was conducted in flooded Spartina alterniflora, with an average depth of 0.5 to $1.0 \mathrm{~m}$.

Both megalopae and juvenile collections were made at the Point aux Pins site. The average salinity at this site was 26.6 psu in 1990 and 20.3 psu in 1991. Average salinity over both years was 23.1 psu. YOY samples were taken in SAV beds at depths $<1.0 \mathrm{~m}$. Dominant SAV at the Point aux Pins site included widgeon grass Ruppia maritima and shoal grass Halodule wrightii. The marsh samples were taken in depths of $<0.5 \mathrm{~m}$ in black needlerush Juncus roemerianus, with lesser amounts of smooth cordgrass Spartina alterniflora.

The Fowl River site had an average salinity of 24.0 psu in 1990 and 6.5 psu in 1991, with a 2 yr average of $11.7 \mathrm{psu}$. This site was used for both megalopae collections and juvenile sampling. Quantitative samples of juveniles were taken in Spartina alterniflora (0.5 to $1.0 \mathrm{~m}$ water depth).

The delta site salinity averaged 4.8 psu in 1990, the only year in which salinity samples were taken. Both megalopal collections and YOY samples were taken at this site. Juvenile samples were taken in SAV beds (tape grass Vallisneria americana, with smaller amounts of Eurasian water milfoil Myriophyllum spicatum and pondweed Potamogeton sp.), where water depth ranged from 0.5 to $1.0 \mathrm{~m}$. Sampling also occurred in adjacent marsh vegetation, which was dominated by bulrush Scirpus robustum, at a depth of less than $0.5 \mathrm{~m}$.

YOY collections. We determined the abundance of juvenile blue crabs $(<25 \mathrm{~mm} \mathrm{CW})$ at 4 sites using a suction dredge. The suction sampling technique has

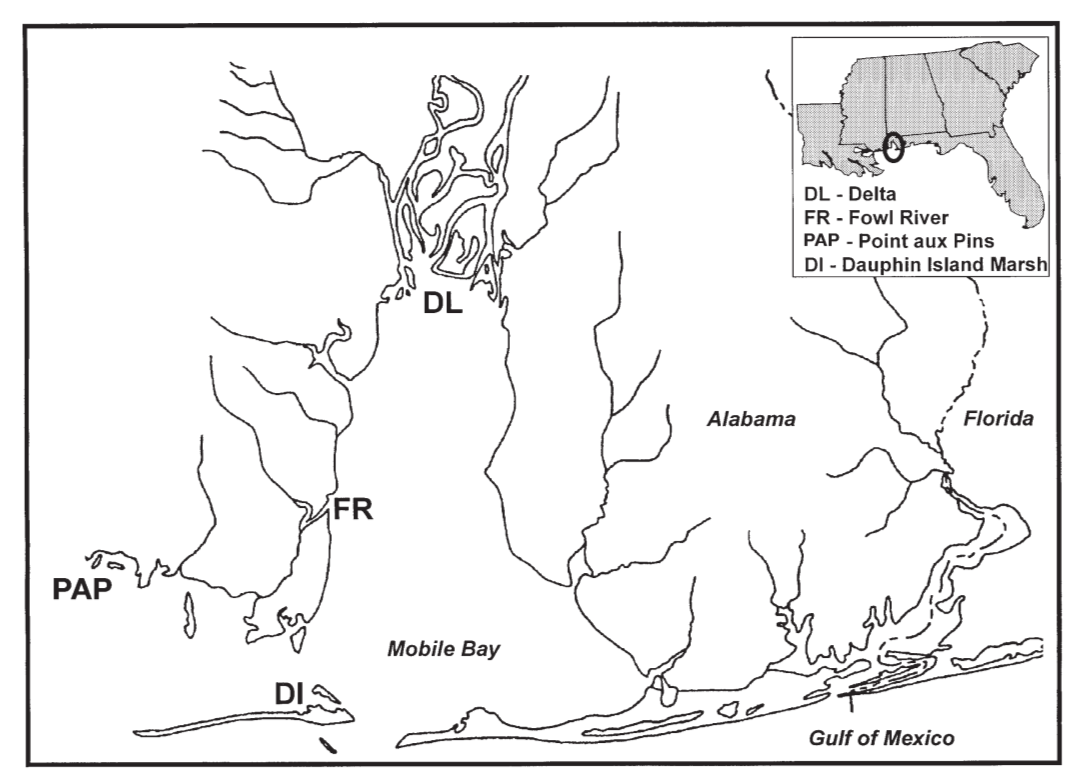

Fig. 1. Study area in coastal Alabama 
been used effectively in Chesapeake Bay eelgrass habitats (Orth \& van Montfrans 1987, Pile et al. 1996), Texas salt marshes and seagrass beds (Zimmerman \& Minello 1984, Zimmerman et al. 1984, Thomas et al. 1990) and local marshes and grass beds in Mobile and Perdido bays (Williams et al. 1990, Stout \& Heck 1991).

Samples were taken by rapidly placing a plastic cylinder (open at both ends) over a $0.307 \mathrm{~m}^{2}$ area in either SAV or marsh habitat. Once the cylinder was in place, it was driven into the sediment to create a tight seal that prevented the exchange of water or organisms, whereupon the water inside the cylinder was evacuated by a pump and passed through a $0.5 \mathrm{~mm}$ mesh collecting bag. Water exiting the collecting bag was then used to refill the cylinder and the contents were again removed and passed through the collecting bag. The suction dredge was then allowed to remove the remainder of the water until the area was dry, and the uncovered bottom was then searched for any remaining blue crabs. This technique has been shown to be approximately 65 to $88 \%$ effective in capturing juvenile blue crabs (Wilson et al. 1990).

Triplicate suction samples were taken haphazardly at biweekly intervals, and all 4 sites were usually sampled on the same day. In Year 1, sampling began on August 8, 1990, and continued through November 14, 1990. In Year 2, to ensure that early settlers were not missed, sampling began 1 mo earlier than the previous year, starting on July 3 and continuing until November 6,1991 . In addition, samples were taken once during February 1991 and March 1992 to determine overwintering crab abundances at each of the study sites. To economize our efforts, the airport site, where the fewest megalopae and YOY crabs were captured, was deleted in 1991.

To determine if the abundance of juvenile crabs was correlated with vegetation characteristics, four $25 \mathrm{~cm}^{2}$ replicate SAV samples were collected (when present) during each sampling effort from the area surrounding the suction samples. Dry weights of each major plant species were quantified by drying at $60^{\circ} \mathrm{C}$ to constant weight in a drying oven. In marsh habitats we quantified vegetation abundance by counting the number of stems enclosed by the cylinder as samples were taken.

Megalopal abundance patterns. As we reported previously (Morgan et al. 1996), triplicate megalopae samples were collected daily from the study sites during summer and fall in both 1990 and 1991 using passive collectors. These collectors have been used effectively to sample blue crab megalopae in Atlantic and Gulf coast estuaries (see Epifanio 1995, Mense et al. 1995, Metcalf et al. 1995, Perry et al. 1995, Rabalais et al. 1995, van Montfrans et al. 1995, Wrona et al. 1995).
The collectors consist of a $38 \times 20 \mathrm{~cm}$ section of 'hog's hair' air-conditioning filters (see Metcalf et al. 1995 for details) that were lined with vexar mesh for support. The filters were stretched around a $38 \mathrm{~cm}$ long PVC pipe of $20 \mathrm{~cm}$ diameter and held in place with rubber bands.

The availability of potential settlers in seagrasses and marshes at each of the vegetated sites was estimated by placing collectors in surface waters immediately seaward of the vegetation. Collectors were sampled daily from August to November 1990 and from July to November 1991 and all megalopae retained each day were washed from the filter material, identified and counted. Here we use these data, which have been previously published (Morgan et al. 1996), to evaluate megalopae-juvenile abundance relationships.

Predation potential for YOY crabs. Predation pressure on juveniles has been shown to be greater in unvegetated than vegetated habitats by a number of investigators, and this may explain, in large part, the importance of vegetation for juvenile blue crabs (Heck \& Wilson 1987, Wilson et al. 1987, Thomas et al. 1990, Williams et al. 1990, Pile et al. 1996). However, it is not known whether predation rates differ between zones in the estuary in similar types of habitats (e.g., marshes or SAV beds). Predators of blue crabs in the Gulf of Mexico include a wide variety of mammals, birds, fishes and macroinvertebrates (Gunter 1945, Darnell 1959, Lambou 1961, Bateman 1965, Day et al. 1973, Evink 1976, Overstreet \& Heard 1978a,b). Blue crabs also frequently cannibalize smaller individuals (Laughlin 1982, Hines et al. 1987, 1990, Moksnes et al. 1997).

We estimated predation rates on juvenile crabs having a carapace width between 5 and $20 \mathrm{~mm}$. Juveniles were collected with a small bag seine from vegetated habitats and returned to the laboratory, where they were tethered by making a loop with a slip knot at one end of a $0.5 \mathrm{~m}$ long monofilament line (using an $8 \mathrm{lb}$ $[\sim 3.6 \mathrm{~kg}]$ test line). This loop was placed around the crab body between the last pair of walking legs and the swimming legs. The slip knot was then secured to the carapace of the crab using cyanoacrylate cement. The other end of the line was tied to a $0.3 \mathrm{~m} \mathrm{~J}$-shaped stake that was shoved into the ground.

Ten measured crabs were placed in each of several potential nursery habitats at both the delta and Point aux Pins sites. The habitats compared were: sand, lowdensity SAV, medium-density SAV (Point aux Pins only), high-density SAV, low-density marsh and highdensity marsh. Tethered crabs were examined every $24 \mathrm{~h}$ to assess loss rates. The remaining line from missing crabs was examined to determine if crabs had escaped, molted or been eaten. Once the results were recorded, missing crabs were replaced so that a full set of crabs was placed out again for the next $24 \mathrm{~h}$. Each 
experiment ran for two $5 \mathrm{~d}$ periods during September in both 1990 and 1991. To determine the effects of vegetation density and species composition on predation rates of juvenile crabs, vegetation was harvested and quantified following each trial, as described above.

There is little chance of mistaking crabs that escape by molting or through tether failure as having fallen victim to predation. Crabs that have molted leave a complete carapace, often with pieces of the gastric mill attached, whereas only fragments of the carapace remain attached to tethers when crabs are preyed upon. Nevertheless, when a tether was occasionally found without a carapace or remnant of a carapace attached, it was dropped from the data set.

Tethering studies have engendered a healthy discussion on the potential artifacts associated with this method (Peterson \& Black 1994, Aronson \& Heck 1995, Zimmer-Faust et al. 1995). Pile et al. (1996) have thoroughly tested for significant habitat-specific tethering artifacts with juvenile blue crabs in seagrass and unvegetated substrates, and found none. Therefore, we do not expect tethering artifacts to influence our conclusions significantly.

Statistical analyses. We calculated correlations between megalopal supply in samples taken 1, 3 and $7 \mathrm{~d}$ prior to suction sampling (data reported by Morgan et al. 1996) and YOY abundance. In this way, we determined whether there were immediate or delayed correlations between post-larval supply and early juvenile crabs.

Differences in abundance of blue crabs among sites, types of vegetation and sampling periods were evaluated using analysis of variance (ANOVA). Data on abundance of blue crabs were $\log _{10}$-transformed prior to analysis. We also calculated correlation coefficients between the abundance of blue crabs and mortality rates, and SAV biomass and marsh stem counts. For tethering experiments, 1-way ANOVA of arcsinetransformed proportions was used to test for differences in the proportion of crabs eaten among habitats in each location.

\section{RESULTS}

\section{YOY temporal and spatial abundance patterns}

During Year 1, abundance of juvenile Callinectes sapidus ranged from 0 at the delta site in September to over $330 \mathrm{~m}^{-2}$ at the Point aux Pins marsh site during late October (Fig. 2). On most sampling dates in 1990, both Point aux Pins SAV and marsh habitats had significantly more juvenile blue crabs than the other sites, and the Point aux Pins SAV site had slightly, but not significantly, greater overall mean crab abundance than the
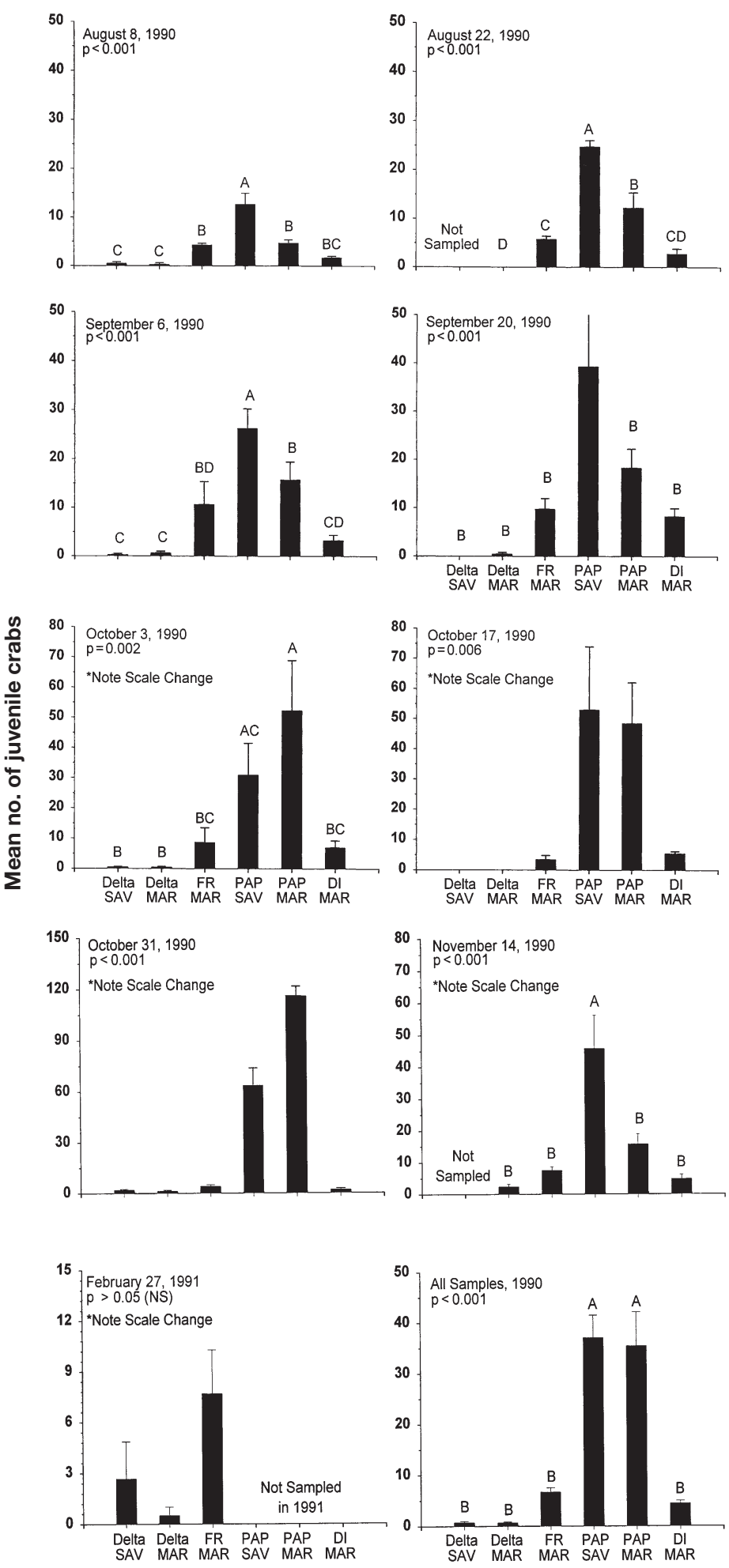

Habitat sampled

Fig. 2. Callinectes sapidus. Mean ( $\pm 15 \mathrm{SE})$ number of crabs collected $0.307 \mathrm{~m}^{-2}$ by suction-sampling during 1990 and 1991. Bars with similar letter not significantly different according to LSD test. SAV: submerged aquatic vegetation; FR: Fowl River; PAP: Point aux Pins; DI: Dauphin Island; MAR: marsh 
Point aux Pins marsh site (Fig. 2). These data indicate that most juveniles occur in the lower portion of the Mobile Bay system.
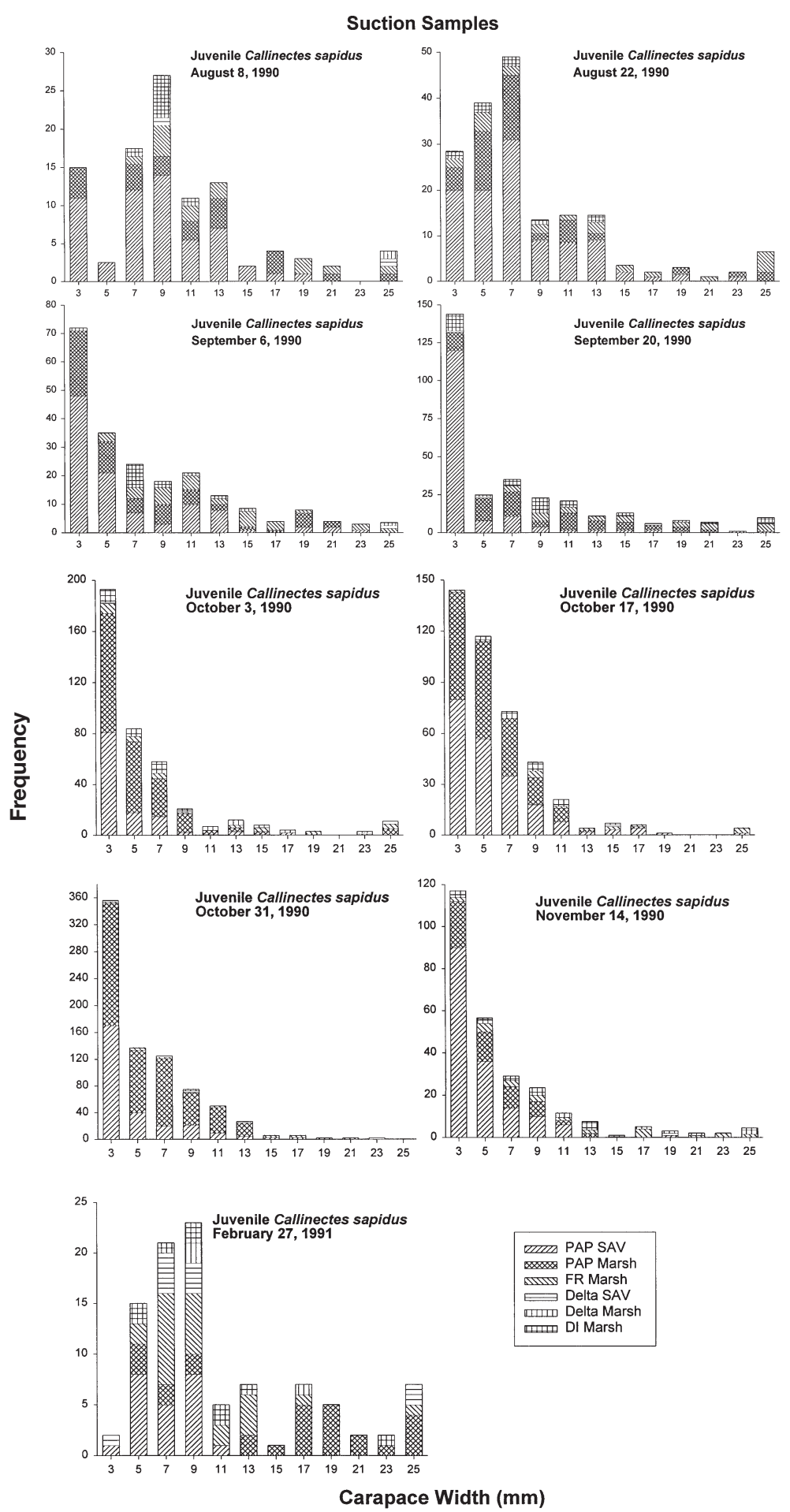

Fig. 3. Callinectes sapidus. Size-frequency distributions of crabs collected by suction-sampling during 1990. Habitat abbreviations as in Fig. 2
For most of the dates sampled in 1990, the largest number of crabs was found in the 2 to $8 \mathrm{~mm}$ carapacewidth size range, with abundance decreasing with increasing size (Fig. 3). Most of these early juvenile crabs were found at the lower bay sites, suggesting their role as primary settlement locations.

In 1991, mean juvenile abundances ranged from 0 at the delta site during most months to nearly $290 \mathrm{~m}^{-2}$ in August at the Point aux Pins SAV site (Fig. 4). As in 1990, greatest numbers were found at both Point aux Pins sampling locations, with abundance in SAV generally significantly greater than that at the marsh site (Fig. 4). However, 1991 abundance was higher at the Fowl River marsh site than in 1990, and juvenile crab abundance there was not significantly lower than at the Point aux Pins marsh site (Fig. 4).

Most of the crabs taken in 1991 were again in the 2 to $8 \mathrm{~mm}$ size classes, and the majority of these, as in 1990, were taken at the Point aux Pins sites (Fig. 5). However, reflecting the greater total numbers captured, many very small crabs were also taken at the Fowl River marsh site. Nevertheless, these data also suggest that the lower bay sites contain the primary habitats for juvenile blue crabs.

SAV biomass was usually greater at the delta site than at Point aux Pins during both 1990 and 1991, especially during late July and in August (Fig. 6). We examined the relationship between the abundance of juvenile blue crabs and SAV biomass and marsh stem counts, using Pearson product-moment correlations, and found no significant correlations between the number of blue crabs and vegetation mea-

Table 1. Callinectes sapidus. Summary of correlations between juvenile abundance and vegetation biomass (SAV) and stem number (Marsh). ${ }^{*} \mathrm{p}<0.5$; ${ }^{* *} p<0.01$

\begin{tabular}{|c|c|c|c|c|c|c|}
\hline \multirow[t]{2}{*}{ Area } & \multicolumn{3}{|c|}{$-1990-$} & \multicolumn{3}{|c|}{$-1991-$} \\
\hline & $\mathrm{r}$ & $\mathrm{p}$ & $\mathrm{n}$ & $\mathrm{r}$ & $\mathrm{p}$ & $\mathrm{n}$ \\
\hline \multicolumn{7}{|c|}{ Point aux Pins } \\
\hline SAV & -0.16 & 0.45 & 24 & 0.40 & $0.04^{*}$ & 27 \\
\hline Marsh & 0.05 & 0.79 & 28 & 0.22 & 0.21 & 34 \\
\hline \multicolumn{7}{|l|}{ Delta } \\
\hline SAV & -0.18 & 0.45 & 19 & 0.12 & 0.49 & 33 \\
\hline Marsh & 0.16 & 0.48 & 23 & 0.13 & 0.47 & 34 \\
\hline \multicolumn{7}{|c|}{ Fowl River } \\
\hline Marsh & 0.18 & 0.40 & 25 & 0.53 & $0.005^{* *}$ & 27 \\
\hline \multicolumn{7}{|c|}{ Dauphin Island } \\
\hline Marsh & -0.10 & 0.60 & 28 & & & \\
\hline
\end{tabular}


surements in 1990 (Table 1). However, in 1991 we found significant positive correlations between SAV biomass and the abundance of juvenile blue crabs at the Point aux Pins site and between marsh stem number and crab abundance at the Fowl River marsh habitat.

Megalopal-juvenile abundance relationships. Relationships between megalopal abundance on the collectors reported by Morgan et al. (1996) and juveniles taken by suction sampling were only infrequently correlated with each other, whether using 1 , 3 or 7 d lags (Fig. 7). Megalopal and juvenile abundance at the Point aux Pins SAV site was not significantly correlated during 1990 or 1991 for 1, 3 or 7 d lags, although there was a trend toward a positive relationship when megalopae numbers were especially high in 1991 (Fig. 7). When the data sets for the $2 \mathrm{yr}$ were combined, significant correlations existed for both 3 and $7 \mathrm{~d}$ lags $(0.05<\mathrm{p}<0.01)$. At the Point aux Pins marsh site, no significant correlations were found (Fig. 7).

At the Fowl River site, significant correlations $(0.05<\mathrm{p}<0.01)$ were found in 1990 between megalopal abundance and juvenile abundance for $1 \mathrm{~d}$ lags, although there was a positive relationship between these parameters for 3 and $7 \mathrm{~d}$ lags as well (Fig. 7). In 1991, similar trends were also observed, but only the $7 \mathrm{~d}$ lagged megalopal data approached significant levels $(0.05<\mathrm{p}<0.06)$. The combined 1990 and 1991 Fowl River data set showed significant correlations $(p<0.01)$ for 1,3 or 7 d lags (Fig. 7 ).

In each of the data sets examined, significant correlations between megalopal abundance and juvenile abundance often occurred when very large numbers of megalopae were found on the collectors (e.g., at means of 200 to 400 per collector: Fig. 7). Inspection of data from suction-sample collections showed, however, that the high number of juveniles that occur after large megalopal collections usually were reduced to prior 'background' levels within $14 \mathrm{~d}$, the time interval between successive suction-sampling efforts. This can be seen by closely examining data when large settlement occurred on the megalopae collectors (cf. Figs 3 \& 5). For example, a large settlement event occurred in the marsh and SAV habitats at Point aux Pins on October 31, 1990 (Fig. 3), yet 2 wk later on November 14, when suction samples were taken, there was little evidence that the settlers from October 31, were still present in the marsh and seagrass habitats, as relatively few small juveniles appeared in the suction samples. Similarly, in 1991 a large settlement event occurred on October 22 at the Point aux Pins marsh and SAV habitats, yet few early juveniles were present when the next suction sampling was done on November 6, 1991.

\section{Predation potential}

At the delta site in 1990, estimated predation potential was high, with all mean losses greater than $80 \%$ (Fig. 8). The greatest survival occurred in the highdensity marsh treatment, although the 1-way ANOVA
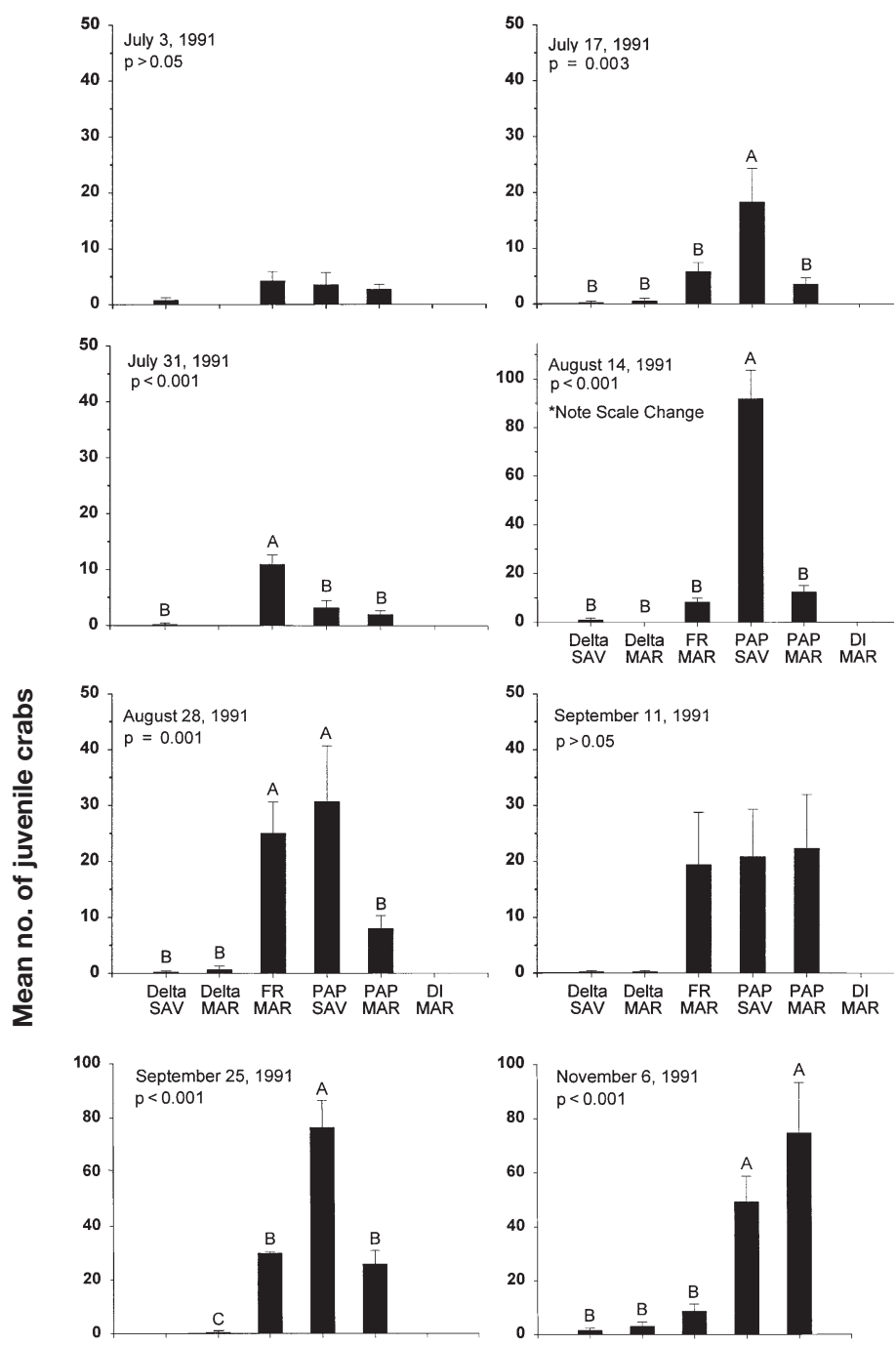

을
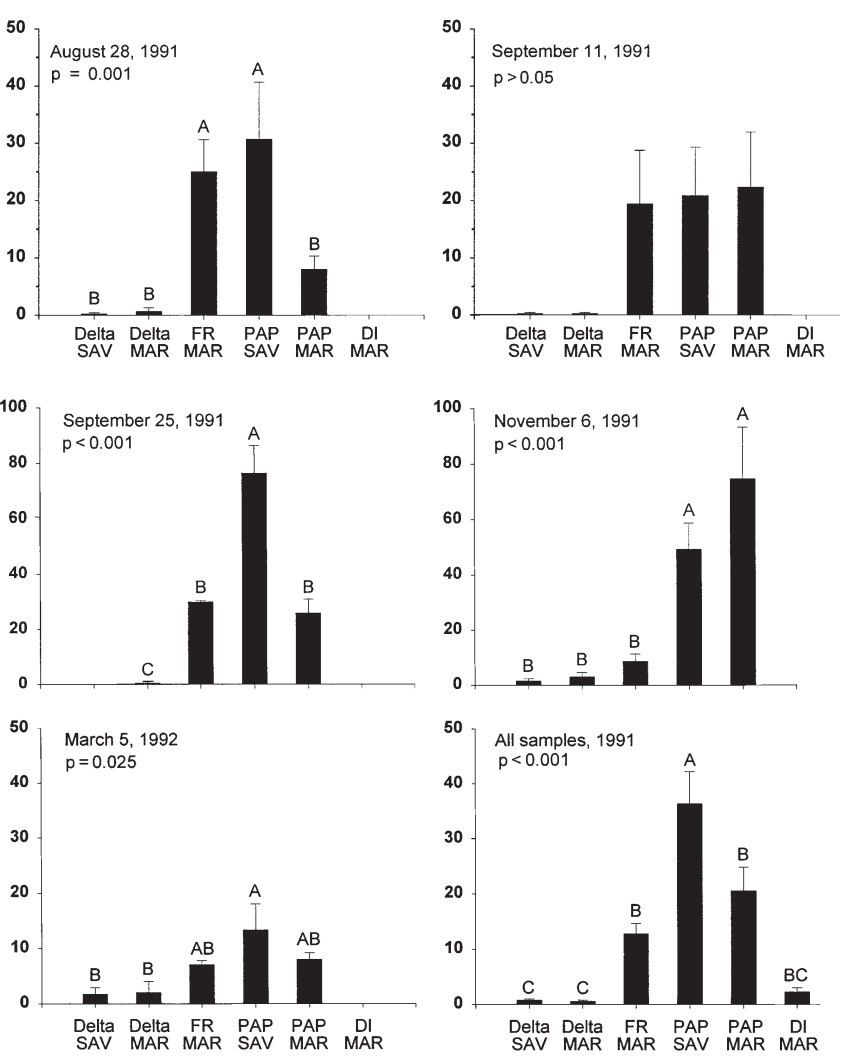

Habitat sampled

Fig. 4. Callinectes sapidus. Mean ( $\pm 15 \mathrm{SE}$ ) number of crabs collected $0.037 \mathrm{~m}^{-2}$ by suction-sampling during 1991. Bars with similar letter not significantly different. Habitat abbreviations as in Fig. 2 


\section{Suction Samples}
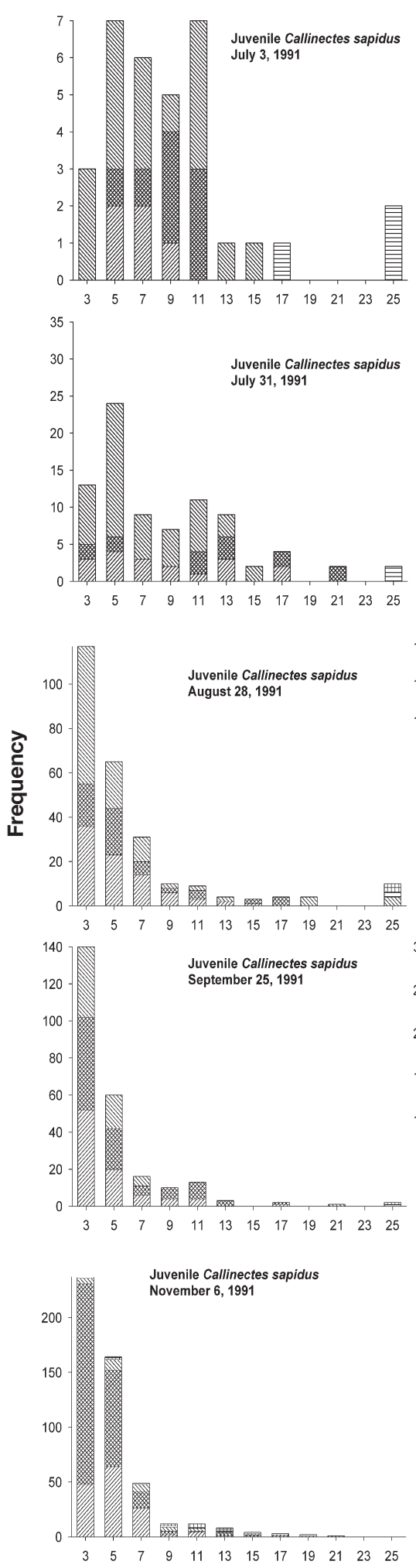

\section{Carapace width $(\mathrm{mm})$}

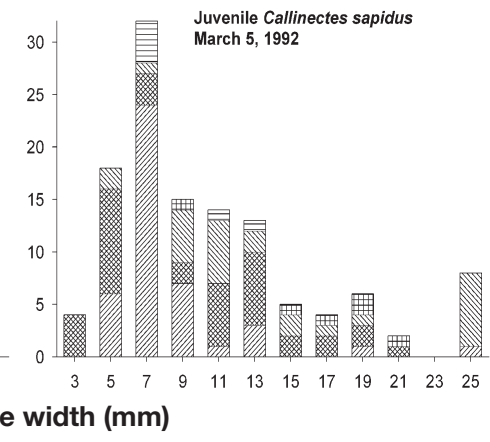

Fig. 5. Callinectes sapidus. Size-frequency distributions of crabs collected by suction-sampling during 1991 and 1992. Habitat abbreviations as in Fig. 2 showed no significant differences among treatments. In 1990, estimated potential predation rates exceeded $80 \%$ of the crabs tethered in all of the Point aux Pins habitats investigated (Fig. 8), with the lowest losses in the high-density SAV treatment. A 1-way ANOVA of arcsine-transformed data found no significant difference in blue crab losses among treatments.

There was little evidence for size-dependent mortality during 1990 tethering studies at either Point aux Pins or the delta study sites (Fig. 8). This does not mean that there is no size refuge for juvenile blue crabs, only that there was no refuge in size among the relatively small range of carapace widths we used in our experiments.

In 1991, losses to predators at Point aux Pins were lower in every habitat than in 1990. Greatest losses were found on sand, while lowest vulnerability existed in highdensity marsh (Fig. 9). However, a 1-way ANOVA on arcsine-transformed data found no significant differences among treatments. At the delta, rates were still high, ranging from $100 \%$ on sand to a low of slightly less than $80 \%$ in the low-density marsh. Differences among habitats were significant at the $\mathrm{p}=0.06$ level, and the
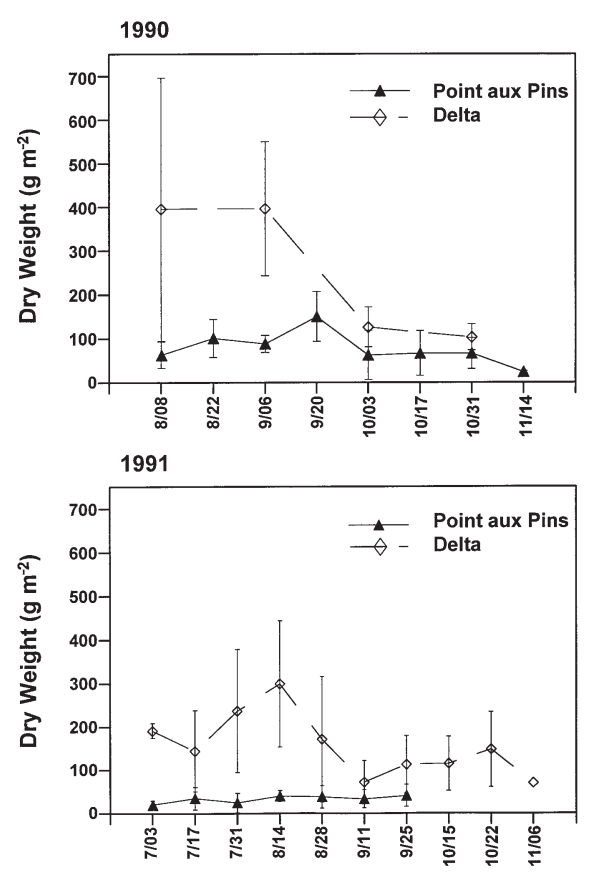

Fig. 6. Mean ( $\pm 15 \mathrm{SE})$ submerged aquatic vegetation dry weights at the Point aux Pins and Delta study sites during 1990 and 1991 ( $=3$ ). Dates presented as mo/d 

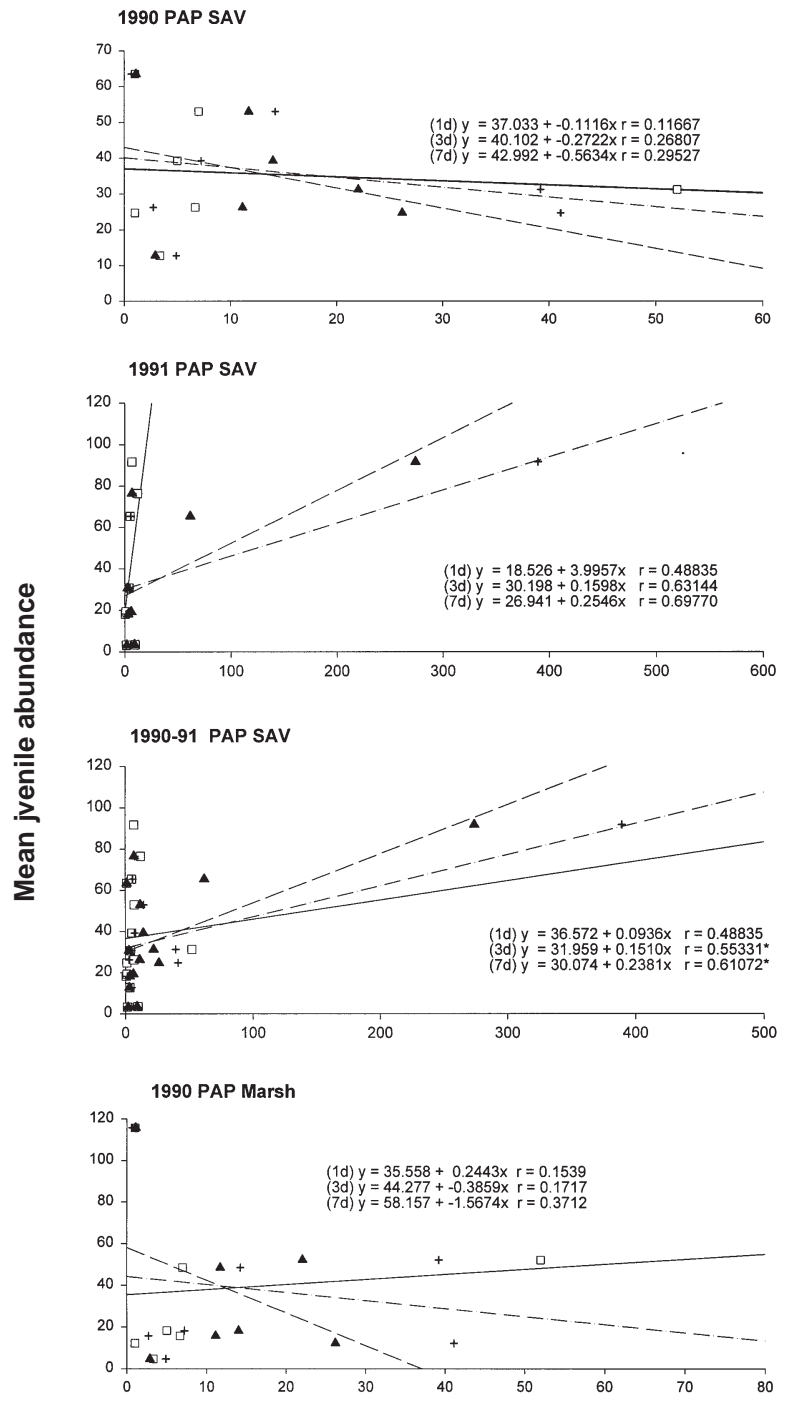

Mean megalopae abundance

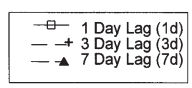

Fig. 7. Callinectes sapidus. Relationships between mean megalopal abundance (n) and mean juvenile abundance (n) at the Point aux Pins (PAP) and Fowl River study sites during 1990 and 1991 (SAV: submerged aquatic vegetation). Signifi-

cant relationships indicated by ${ }^{*} \mathrm{p}<0.05$ and ${ }^{* *} \mathrm{p}<0.01$

only significant pairwise comparison $(\mathrm{p}<0.05)$ was between the sand and the low-density marsh treatments.

During 1991, the largest size category of crabs (20 to $21 \mathrm{~mm}$ CW) used at Point aux Pins survived in greatest numbers (Fig. 9). As in 1990, there was little evidence for size selectivity by predators at the delta during 1991 (Fig. 9).

Finally, Fig. 10 shows the relationship between SAV biomass and the percentage of juvenile crabs con-
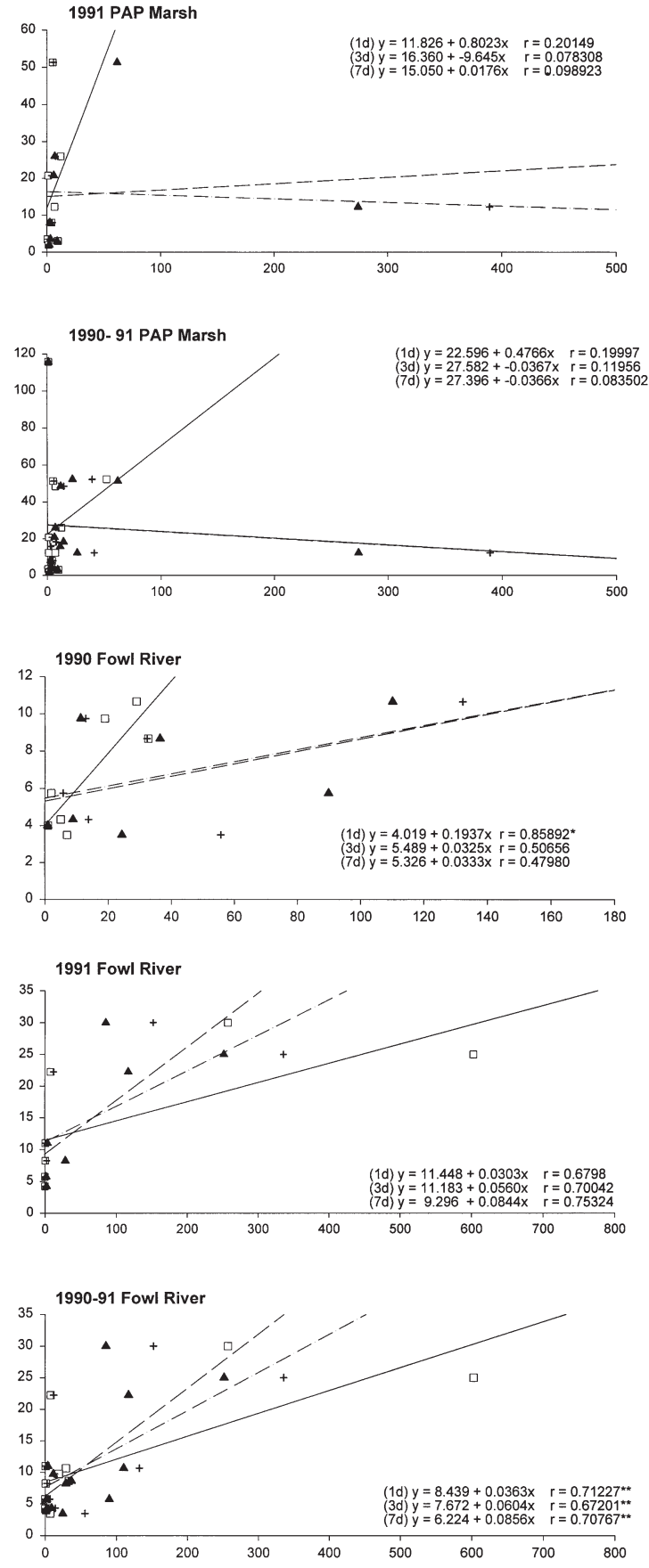

sumed at the Point aux Pins tethering site, as well as data from 2 similar tethering studies in eelgrass beds in New Jersey (Wilson et al. 1990) and in the Chesapeake Bay (Pile et al. 1996). Each of these studies was done in the summer-fall period, with similar-sized crabs in roughly similar salinities. As Fig. 10 shows, SAV biomasses during our tethering studies were quite low, suggesting that they may have been insufficient to bring about large reductions in predation losses compared to those experienced on unvegetated substrates. 

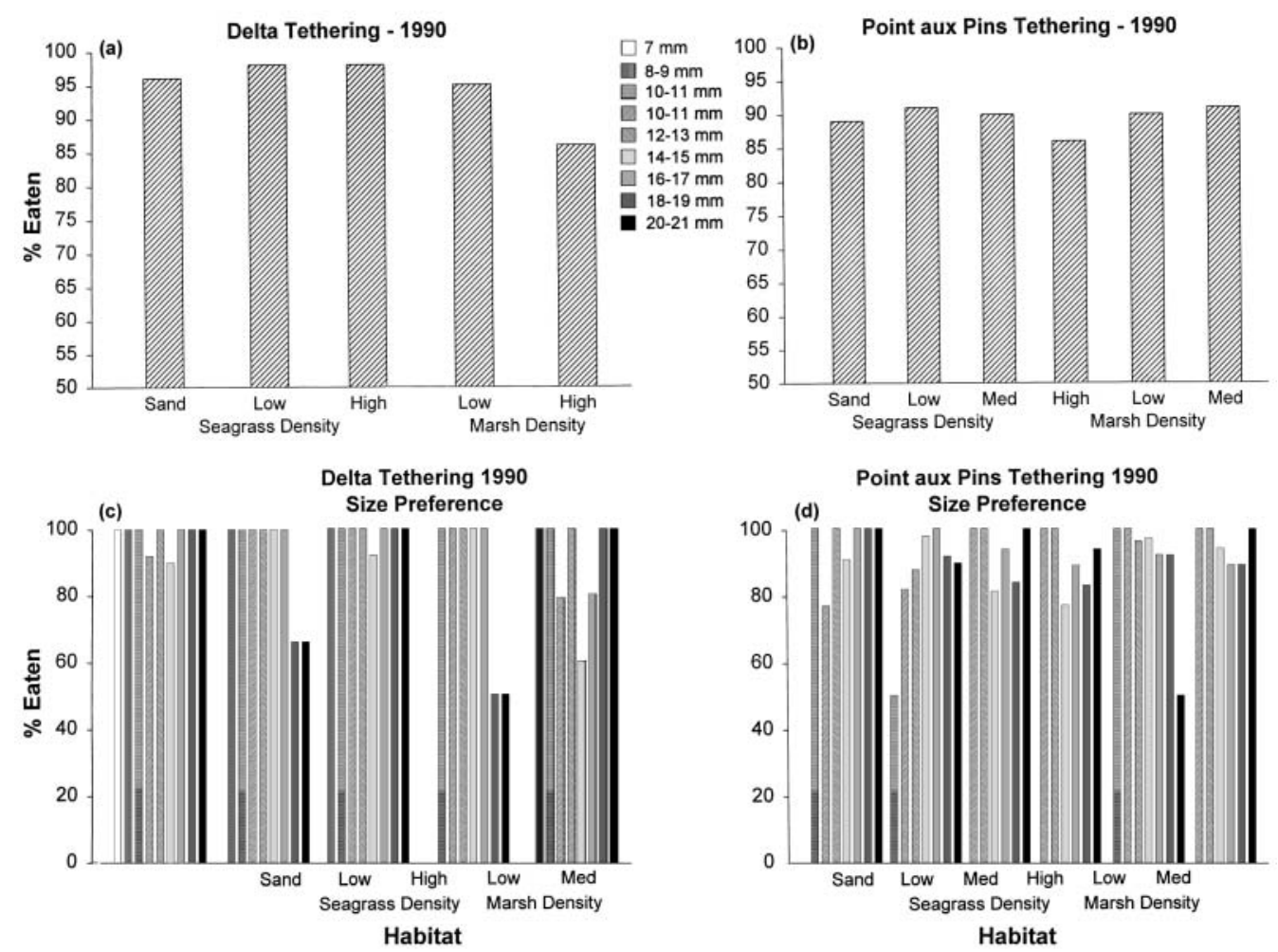

Fig. 8. Callinectes sapidus. Percentages and sizes of crabs eaten during 1990 tethering studies at the Delta and Point aux Pins study sites
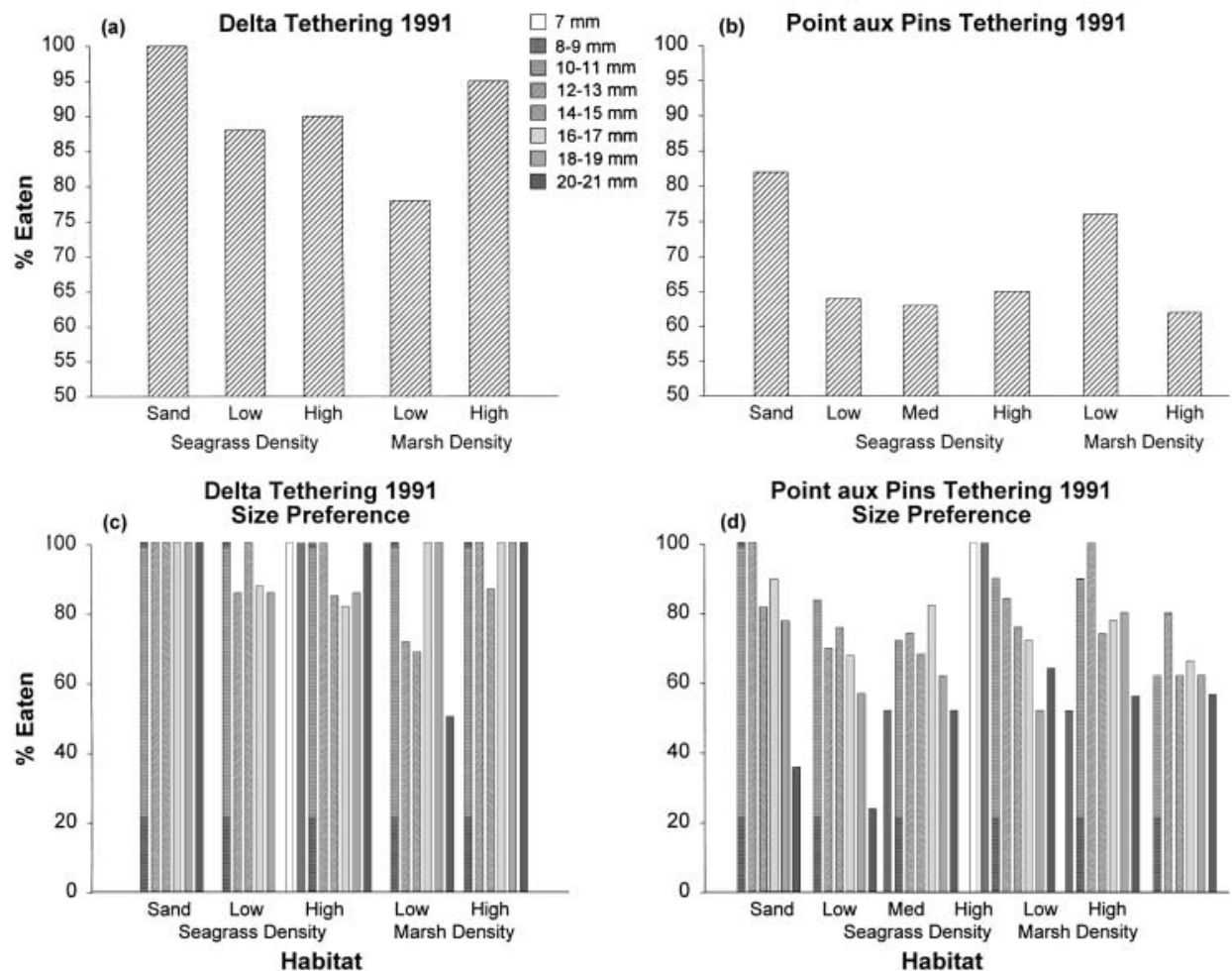

Fig. 9. Callinectes sapidus. Percentages and sizes of crabs eaten during 1991 tethering studies at the Delta and Point aux Pins study sites 


\section{DISCUSSION}

\section{Correspondence between megalopal and YOY abundance}

Studies on decapod crustaceans have often produced differing results regarding the importance of postlarval supply in determining juvenile abundance in coastal nursery habitats. For example, the rock lobster harvest in Western Australia can be quite accurately predicted by measuring postlarval abundance in the rocky reef nursery grounds (see Pearse \& Phillips 1994 for a summary), and clawed lobsters in the Gulf of Maine have been found to exhibit significant correlations between postlarval supply and juvenile abundance in nursery habitats (Incze et al. 1997, Wahle \& Incze 1997, Palma et al. 1998). Conversely, studies of Dungeness crabs Cancer magister in Washington state (USA) (Eggleston \& Armstrong 1995), rock crabs C. irroratus in the Gulf of Maine (Palma et al. 1998), and blue crabs in the Chesapeake Bay (Pile et al. 1996) found substantial density-dependent mortality that eliminated the positive relationships between postlarval supply and juvenile abundance.

In the Eggleston \& Armstrong (1995) study, a decoupling of postlarval supply and density of firststage juvenile Dungeness crabs occurred within a $48 \mathrm{~h}$ period. Only in areas where predators were excluded was there a significant postlarval-early juvenile relationship. Rock crabs are also highly susceptible to predators, and early post-settlement mortality appears to eliminate the influence of postlarval supply (Palma et al. 1998). Pile et al. (1996) found early blue crab juveniles to suffer very high density-dependent losses, much of which appeared to be due to cannibalism from slightly larger blue crabs (see Moksnes et al. 1997).

In agreement with prior crab studies, we generally found, for Callinectes sapidus, little correspondence between postlarval abundance and juvenile numbers unless there were very large megalopal settlement events (Fig. 7). Even when there were significant correlations between megalopal and juvenile abundance with lags of 1,3 and $7 \mathrm{~d}$, by $14 \mathrm{~d}$ after settlement there was no evidence that even these large settlement episodes had resulted in significant numbers of surviving juvenile crabs (Figs $3 \&$ 5). Our tethering results suggest that high mortality of early instar crabs eliminates most of the individuals produced by episodic settlement events. Therefore, even though megalopal settlement rates are much higher in the Gulf of Mexico than those recorded in Atlantic coast estuaries like the Chesapeake Bay, high rates of density-dependent mortality appear to quickly reduce juvenile crab numbers to levels approaching those in mid-Atlantic estu-

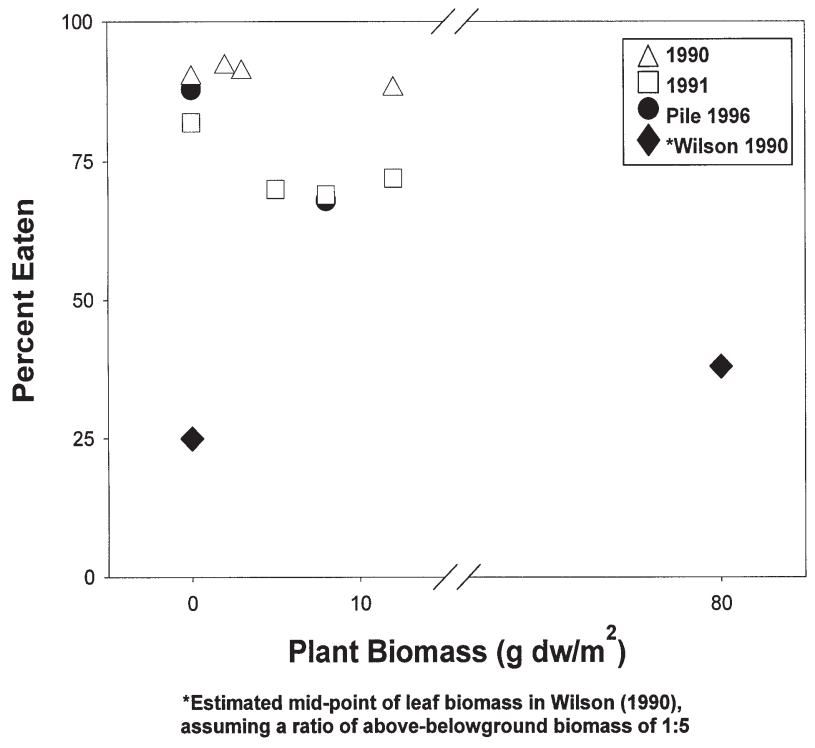

Fig. 10. Callinectes sapidus. Relationships between percentage of tethered crabs eaten and plant biomass among studies conducted on the Atlantic coast (Wilson et al. 1990, Pile et al. 1996) and Gulf coasts (this study)

aries (Heck \& Coen 1995), and somewhere between 7 and $14 \mathrm{~d}$ eliminate any evidence that large megalopal settlement had taken place.

Whether differences in the degree of correspondence between postlarval supply and juvenile abundance reported for lobsters and crabs represent some fundamental differences in life-history strategies among these functional groups of decapods, perhaps with respect to the prevalence of cannibalism among these taxa, or whether they are simply species-specific patterns, is not clear. Answering this question, with additional information from other species of lobsters and crabs should have a great deal of relevance for fishery managers.

\section{Relative role of upper- and lower-bay nursery habitats}

Our prior megalopal studies clearly showed that most settlement was confined to the lower reaches of the Mobile Bay system (Morgan et al. 1996). Similarly, juvenile abundance was greatest in the lower half of the Mobile Bay system, although densities of several larger juvenile crabs $\mathrm{m}^{-2}$ were common in the late summer and early fall in the delta (Figs 2 to 5). This suggests that larger juveniles move up-bay toward lower-salinity waters and oligohaline marshes and SAV beds. Therefore, these lower-salinity marsh and SAV habitats appear to have a significant nursery 
function for larger juveniles. However, it appears that the lower Bay SAV beds and, to a substantial but lesser extent, salt marshes, are the primary nursery habitats for the earliest juvenile blue crab instars in the Mobile Bay system. This is consistent with findings of earlier studies on both the mid-Atlantic and Gulf coasts (Orth \& van Montfrans 1987, Thomas et al. 1990, Williams et al. 1990).

The failure to frequently find significant positive correlations between YOY abundance and SAV biomass or marsh stem density was somewhat surprising, given that prior work has shown survival of decapod crustaceans to be an increasing function of vegetation density, both in freshwater and marine environments (see review by Heck \& Crowder 1991). Perhaps the initial decision to settle may be a qualitative one (i.e., is vegetation present or not, as originally suggested by Bell \& Westoby [1986]), with subsequent redistribution of juveniles by dispersion and differential survival. Alternatively, and in our estimation more likely, is the possibility that the low-density of vegetation at our study sites in the lower bay may have obscured any significant relationships between SAV biomass and crab abundance.

\section{Predation rates}

Predation potential at our sites, as estimated by our tethering experiments, was very high compared to similar studies of juvenile blue crabs in eelgrass beds along the Atlantic coast in New Jersey and Chesapeake Bay (Wilson et al. 1990, Heck \& Coen 1995) (Fig. 10). This is consistent with reports for other crab species, in which greatest predation losses occurred in lower latitudes (Heck \& Wilson 1987). Moreover, as Heck \& Wilson had found previously, predation losses varied substantially from year to year both within and between habitats, with the value of SAV as protection from predators also being spatially and temporally variable. For example, at Point aux Pins, losses to predators were very high and quite similar among habitats in 1990. In contrast, overall rates were lower in 1991, and there was substantially greater survival value in being associated with vegetation during this year (Figs 8 \& 9). This supports earlier notions that the value of SAV nursery habitats for small crustaceans can vary greatly, presumably as a function of differential annual success in recruitment by their predator species. In addition, the low SAV biomass during our tethering studies, which ranged from slightly above 0 to approximately $23 \mathrm{~g}$ dry wt $\mathrm{m}^{-2}$ (Fig. 10), suggests that these values were insufficient to produce large effects on predation rates.

\section{Summary and conclusions}

Blue crab megalopae occurred abundantly at our study sites in the lower half of Mobile Bay and at Point aux Pins throughout the 2 yr study period (Morgan et al. 1996), and probably recruit year-round, as has been found elsewhere in the Gulf of Mexico (King 1971). However, only after especially large recruitment events did we find significant correlations between megalopal and juvenile abundance, and these relationships became decoupled within 1 to $2 \mathrm{wk}$. Because average juvenile abundance, which ranged from approximately 30 to $300 \mathrm{~m}^{-2}$, was of the same magnitude as that reported from Chesapeake Bay (45 to $90 \mathrm{~m}^{-2}$; Orth \& van Montfrans 1987), and because megalopae numbers entering Mobile Bay were very large (Rabalais et al. 1995, Morgan et al. 1996), there must be high juvenile mortality rates to produce such rapid decreases in abundance of early benthic settlers.

Our data also suggested that mortality rates among sites were highest within $14 \mathrm{~d}$ after large settlement events, indicating the importance of density-dependent mortality soon after settlement. The mean predation potential estimated for crabs in SAV and marsh vegetation during 1990 and 1991 ( 80\% consumed d ${ }^{-1}$ ) is substantially higher than values reported from Chesapeake Bay (68\%; Pile 1993) or New Jersey (25\%; Wilson et al. 1990). Because of the high mortality rates characteristic of low latitudes, it appears that the importance of SAV and marsh habitats as primary nursery grounds for juvenile blue crabs and refuge from predation in lower latitudes is relatively more important than in higher latitudes, where predation pressure on early juvenile crabs appears to be lower and the importance of larval supply rates greater.

Acknowledgements. We thank Melanie Mallon, Todd Bowen, Barbara Randall, Tim Thibault, Susan Sklenar and, especially, Jill Busby High, for technical assistance, Carolyn Wood for keyboarding and figure preparation, and Eric Crandall, Debbie Kilbane and Tricia Spitzer for commenting on previous drafts. Financial support provided by NOAA (MARFIN Grant Number NA90AAHMF 761) and the Dauphin Island Sea Laboratory This is Contribution No. 333 of the Dauphin Island Sea Laboratory.

\section{LITERATURE CITED}

Adkins G (1972) Notes on the occurrence and distribution of the rhizocephalan parasite (Loxothylacus texanus Boschma) of blue crabs (Callinectes sapidus Rathbun) in Louisiana estuaries. La Wildl Fish Comm Tech Bull 2:1-13

Aronson RB, Heck KL Jr (1995) Tethering experiments and hypothesis testing in ecology. Mar Ecol Prog Ser 121:307-309

Bateman HA (1965) Clapper (Pallus longirostrus) studies on Grand Terre Island, Jefferson Parish, Louisiana. Masters thesis, Louisiana State University, Baton Rouge 
Bell JD, Westoby M (1986) Abundance of macrofauna in dense seagrass is due to habitat preference, not predation. Oecologia (Berlin) 68:205-209

Blanton EE, Wenner EL, Werner F, Knotts DW (1996) Effects of wind-generated coastal currents on the transport of blue crab megalopae on a shallow continental shelf. Bull Mar Sci 57:739-752

Boesch DF, Turner RE (1984) Dependence of fishery species on salt marshes: the role of food and refuge. Estuaries 7: $460-468$

Costlow JD, Bookhout CG (1959) The larval development of Callinectes sapidus Rathbun, reared in the laboratory. Biol Bull (Woods Hole) 116:373-396

Cushing DH (1982) Marine ecology and fisheries. Cambridge University Press, Cambridge, MA

Darnell RM (1959) Studies of the life history of the blue crab (Callinectes sapidus Rathbun) in Louisiana waters. Trans Am Fish Soc 88:294-304

Daugherty FM Jr (1952) The blue crab investigation, 1949-50. Tex J Sci 4:77-84

Day JW, Smith WG, Wagner RR, Stone WC (1973) Community structure and carbon budget of a marsh and shallow bay estuarine system in Louisiana. La State Univ Stud Biol Sci Ser LSU-SG-72-04:80

Eggleston DB, Armstrong D (1995) Pre- and post-settlement determinants of estuarine Dungeness crab recruitment. Ecol Monogr 65:193-216

Epifanio CE (1995) Transport of blue crab (Callinectes sapidus) larvae in the waters off mid-Atlantic States. Bull Mar Sci 57:713-725

Evink GL (1976) Some aspects of the biology of the blue crab, Callinectes sapidus Rathbun, on Florida's Gulf coast. Masters thesis, University of Florida, Gainesville

Gaines SD, Bertness MD (1992) Dispersal of juveniles and variable recruitment in sessile marine species. Nature (Lond) 360:579-580

Gaines SS, Brown S, Roughgarden J (1985) Spatial variation in larval concentrations as a cause of spatial variation in settlement for the barnacle, Balanus glandula. Oecologia (Berl) 67:267-272

Gunter G (1945) Studies on marine fishes of Texas. Publ Inst Mar Sci Univ Tex 1:1-190

Heck KL Jr, Coen LD (1995) Predation and abundance of juvenile blue crabs: a comparison of selected east and Gulf coast studies. Bull Mar Sci 57:877-883

Heck KL Jr, Crowder LB (1991) Habitat structure and predator-prey interaction in vegetated aquatic systems. In: Bell S, McCoy E, Mushinsky H (eds) Habitat structure: the physical arrangement of objects in space. Chapman \& Hall, New York, p 281-299

Heck KL Jr, Orth RJ (1989) Structural components of eelgrass (Zostera marina) meadows in the lower Chesapeake Baydecapod Crustacea. Estuaries 3:289-295

Heck KL Jr, Thoman TA (1984) The nursery role of seagrass meadows in the upper and lower reaches of the Chesapeake Bay. Estuaries 7:70-92

Heck KL Jr, Wilson KA (1987) Predation rates on decapod crustaceans in latitudinally separated seagrass communities: a study of spatial and temporal variation using tethering techniques. J Exp Mar Biol Ecol 107:87-100

Hines AH, Lipcius RN, Haddon AM (1987) Population dynamics and habitat partitioning by size, sex, and molt stage of blue crabs Callinectes sapidus in a subestuary of central Chesapeake Bay. Mar Ecol Prog Ser 36: $55-64$

Hines AH, Haddon AM, Wiechert LA (1999) Guild structure and foraging impact of blue crabs and epibenthic fish in a subestuary of Chesapeake Bay. Mar Ecol Prog Ser 67: 105-126

Incze LS, Wahle RA, Cobb JS (1997) Quantitative relationships between postlarval production and benthic recruitments in lobsters, Homarus americanus. Mar Freshw Res 48:729-743

King BD III (1971) Study of migratory patterns of fish and shellfish through a natural pass. Tex Parks Wildl Dep Tech Ser 9:1-54

Lambou VW (1961) Utilization of macrocrustaceans for food by freshwater fishes in Louisiana and its effects on the determination of predator-prey relations. Prog Fish-Cult 23:18-25

Laughlin RA (1982) Feeding habits of the blue crab, Callinectes sapidus Rathbun, in Appalachicola estuary. Bull Mar Sci 32:807-822

Mense DJ, Power MH, West T, Kinchloe K (1995) Settlement of brachyuran postlarvae along the North Carolina coast. Bull Mar Sci 57:793-806

Metcalf KS, van Montfrans J, Lipcius RN, Orth RJ (1995) Settlement indices for blue crab megalopae in the York River, Virginia: temporal relationships and statistical efficiency. Bull Mar Sci 57:781-792

Milliken MR, Williams AB (1984) Synopsis of biological data on the blue crabs, Callinectes sapidus, Rathbun. NOAA Tech Rep NMFS (1: FAO Fish Synop) 138:1-39

Moksnes PO, Lipcius RN, Pihl L, van Montfrans J (1997) Cannibal-prey dynamics in young juveniles and postlarvae of the blue crab. J Exp Mar Biol Ecol 215:157-187

More WR (1969) A contribution to the biology of the blue crab (Callinectes sapidus Rathbun) in Texas, with a description of the fishery. Tex Parks Wildl Dep Tech Ser 1:1-31

Morgan SG, Zimmer-Faust R, Heck KL Jr, Coen LD (1996) Population regulation of blue crabs Callinectes sapidus in the northern Gulf of Mexico: postlarval supply. Mar Ecol Prog Ser 133:73-88

Nixon SW (1989) Between coastal marshes and coastal watersa review of twenty years of speculation and research on the role of salt marshes in estuarine productivity and water chemistry. In: Hamilton P, McDonald KB (eds) Estuarine and wetland processes. Plenum Publ Corp, New York, p 437-525

NMFS (National Marine Fisheries Service) (1988) Marine fisheries statistics of the United States. Department of Commerce, NOAA, Washington, DC

Olmi EJ III (1995) Ingress of blue crab megalopae in the York River, Virginia, 1987-1989. Bull Mar Sci 57:753-780

Olmi EJ III, Orth RJ (1995) Introduction to the proceedings of the blue crab recruitment symposium. Bull Mar Sci 57: $707-712$

Orth RJ, van Montfrans J (1987) Utilization of seagrass meadow and tidal marsh creek by blue crabs Callinectes sapidus. I. Seasonal and annual variations in abundance with emphasis on post-settlement juveniles. Mar Ecol Prog Ser 41:283-294

Overstreet RM, Heard RW (1978a) Food of the red drum, Sciaenops ocellata, from Mississippi Sound. Gulf Res Rep 6: 131-135

Overstreet RM, Heard RW (1978b) Food of the Atlantic croaker, Micropogonias undulatus, from Mississippi Sound and the Gulf of Mexico. Gulf Res Rep 6:145-152

Palma AT, Wahle RA, Steneck RS (1998) Different early postsettlement strategies between American lobsters Homarus americanus and rock crabs Cancer irroratus in the Gulf of Mexico. Mar Ecol Prog Ser 162:215-225

Pearse AF, Phillips BF (1994) Oceanic processes, puerulus settlement and recruitment of the western rock lobster Panulirus cygnus. In: Sammarco PW, Heron ML (eds) The bio- 
physics of marine larval dispersal. American Geophysical Union, Washington, DC, p 279-306

Penry DL (1982) Utilization of a Zostera marina and Ruppia maritima habitat by four decapods with emphasis on Callinectes sapidus. Masters thesis, College of William and Mary, Williamsburg, VA

Perry HM (1975) The blue crab fishery in Mississippi. Gulf Res Rep 5:39-57

Perry HM, Eleutherius CK, Trigg CB, Warren JR (1995) Settlement patterns of Callinectes sapidus megalopae in Mississippi Sound: 1991,1992). Bull Mar Sci 57:821-833

Peterson CH, Black R (1994) An experimentalists challenge: when artifacts of intervention interact with treatments. Mar Ecol Prog Ser 111:289-297

Pile AJ, Lipcius RN, van Montfrans J, Orth RJ (1996) Densitydependent settler-recruit-juvenile relationships in blue crabs. Ecol Monogr 66:277-300

Rabalais NN and 11 others (1995) Settlement of Callinectes sapidus megalopae on artificial collectors in four Gulf of Mexico estuaries. Bull Mar Sci 57:855-876

Rothschild BJ (1986) Dynamics of marine fish populations. Harvard University Press, Cambridge, MA

Sissenwine MP (1984) Why do fish populations vary? In: May RM (ed) Exploitation of marine communities. SpringerVerlag, New York

Smyth PO (1980) Callinectes (Decapoda: Portunidae) larvae in the Middle Atlantic Bight, 1975-77) Fish Bull (Wash DC) 78:251-261

Stout JP, Heck KL Jr (1991) Reintroduction of oligohaline estuarine grassbeds: techniques and functional ecology. In: Wev FJ (ed) Proceedings of the 16th Annual Conference on Wetlands Restoration and Creation. Hillsborough Community College, Tampa, FL, p 180-199

Stuck KC, Perry HM (1981) Observations on the distribution and seasonality of portunid megalopae in Mississippi coastal waters. Gulf Res Rep 7:93-95

Tagatz ME (1968) Biology of the blue crab, Callinectes sapidus Rathbun, in the St. John's River, Florida. Fish Bull (Wash DC) 67:17-33

Tatum WM (1982) The blue crab fishery of Alabama. In: Perry HM, van Engel WA (eds) Proceedings of the Blue Crab Colloquium, October 18-19, 1979, Biloxi, Mississippi. Gulf States Marine Fisheries Commission, Ocean Springs, MI

Thayer GW, Stuart HH (1974) The bay scallop makes its bed of seagrass. Mar Fish Rev 36:27-30

Editorial responsibility: Otto Kinne (Editor),

Oldendorf/Luhe, Germany
Thomas JL, Zimmerman RJ, Minello T (1999) Abundance patterns of juvenile blue crabs (Callinectes sapidus) in nursery habitats of two Texas bays. Bull Mar Sci 46:115-125

Truesdale FM, Andryszak BL (1983) Occurrence and distribution of reptant decapod crustacean larvae in neritic Louisiana waters: July 1976. Cont Mar Sci 26:37-53

Turner RE (1977) Intertidal vegetation and commercial yields of penaeid shrimp. Trans Am Fish Soc 106:411-416

van Montfrans J, Epifanio CE, Knott DM, Lipcius RN, Mense DJ, Metcalf KS, Olmi EJ III, Orth RJ, Posey MH, Wenner EL, West TL (1995) Settlement of blue crab postlarvae in western North Atlantic estuaries. Bull Mar Sci 57:834-854

Wahle RA, Incze LS (1997) Pre- and post-settlement processes in recruitment of the American lobster. J Exp Mar Biol Ecol 217:179-207

Weinstein MP, Brooks HA (1983) Comparative ecology of nekton residing in a tidal creek and adjacent seagrass meadow: community composition and structure. Mar Ecol Prog Ser 12:15-27

Williams AB (1984) Shrimps, lobsters and crabs of the Atlantic coast. Smithsonian Institution Press, Washington, DC

Williams AH, Coen LD, Stoelting MS (1999) Seasonal abundance, distribution and habitat selection of juvenile Callinectes sapidus (Rathbun) in the northern Gulf of Mexico. J Exp Mar Biol Ecol 137:165-183

Wilson KA, Heck KL Jr, Able KW (1987) Juvenile blue crab (Callinectes sapidus) survival: an evaluation of eelgrass (Zostera marina) as refuge. Fish Bull (Wash DC) 85:53-58

Wilson KA, Able KW, Heck KL Jr (1990) Predation rates on juvenile blue crabs in estuarine nursery habitats: evidence for the importance of macroalgae (Ulva lactuca). Mar Ecol Prog Ser 58:243-251

Wrona AB, Wiegert RG, Bishop TD (1995) Initial report of settlement patterns of brachyuran megalopae at Sapelo Island, Georgia, USA. Bull Mar Sci 57:807-820

Zimmer-Faust RK, Fielder DR, Heck KL, Coen LD, Morgan SG (1994) Effects of tethering on predatory escape by juvenile blue crabs. Mar Ecol Prog Ser 111:299-303

Zimmerman RJ, Minello TJ (1984) Densities of Penaeus aztecus, Penaeus setiferus and other natant macrofauna in a Texas salt marsh. Estuaries 7:421-433

Zimmerman RJ, Minello TJ, Zamora G Jr (1984) Selection of vegetated habitat by brown shrimp, Penaeus aztecus, in a Galveston Bay salt marsh. Fish Bull (Wash DC) 82: 325-336

Submitted: August 20, 2000; Accepted: December 8, 2000 Proofs received from author(s): August 30, 2001 